\title{
MULTILEVEL ANALYSIS ON THE CONTEXTUAL EFFECT OF THE INTEGRATED HEALTH POST ON THE USE OF NON- COMMUNICABLE DISEASE SCREENING SERVICE
}

\author{
Riza Firdaus',2), Yulia Lanti Retno Dewi'3), Bhisma Murti²) \\ ${ }^{1}$ Semitau Community Health Center, Kapuas Hulu, West Kalimantan \\ 2)Masters Program in Public Health, Universitas Sebelas Maret \\ 3)Faculty of Medicine, Universitas Sebelas Maret
}

\begin{abstract}
Background: Non-Communicable Diseases (NCDs) is the leading cause of death worldwide and a serious threat to health in low and middle income countries. This can be prevented by early detection and monitoring of NCDs risk factors. This study aimed to investigate the contextual effect of the integrated health post on the use of non- communicable disease screening service.

Subjects and Method: A cross sectional study was carried out at 25 integrated health posts (posbindu) in Kapuas Hulu, West Kalimantan, Indonesia, from August to October 2019. A sample of 200 study subjects was selected by fixed disease sampling. The dependent variable was the use of NCD screening service. The independent variables were subjective norm, health information, family support, cadre support, health beha-vior, health status, attitude, and intention. The data were collected by questionnaire and analyzed by a multiple multilevel logistic regression run on Stata 13.

Results: The use of NCD screening service increased with supportive subjective norm $(\mathrm{b}=$ o.88; $95 \% \mathrm{CI}=0.01$ to $1.75 ; \mathrm{p}=0.045)$, high health information exposure $(\mathrm{b}=1.10 ; 95 \% \mathrm{CI}=$ 0.18 to $2.02 ; p=0.019)$, strong family support $(b=0.94 ; 95 \% \mathrm{CI}=0.05$ to $1.83 ; \mathrm{p}=0.037$, strong cadre support $(b=0.87 ; 95 \% \mathrm{CI}=0.01$ to $1.73 ; \mathrm{p}=0.047)$, health behavior $(\mathrm{b}=1.39 ; 95 \%$ $\mathrm{CI}=0.49$ to $2.30 ; \mathrm{p}=0.002)$, had $\mathrm{NCD}(\mathrm{b}=1.30 ; 95 \% \mathrm{CI}=0.19$ to $2.41 ; \mathrm{p}=0.021)$, positive attitude $(\mathrm{b}=0.98 ; 95 \% \mathrm{CI}=0.12$ to $1.84 ; \mathrm{p}=0.025)$, and strong intention $(\mathrm{b}=1.14 ; 95 \% \mathrm{CI}=$ 0.26 to 2.01; $\mathrm{p}=0.010)$. Posbindu had negligible contextual effect on the use of NCD screening service with intra-class correlation $($ ICC $)=7.1 \%$.

Conclusion: The use of NCD screening service increases with supportive subjective norm, high health information exposure, strong family support, strong cadre support, health behavior, had NCD, positive attitude, and strong intention. Posbindu has negligible contextual effect on the use of NCD screening service.
\end{abstract}

Keywords: non-communicable disease, screening service, integrated health post

\section{Correspondence:}

Riza Firdaus. Masters Program in Public Health, Universitas Sebelas Maret. Jl. Ir. Sutarmi 36A, Surakarta 57126, Central Java, Indonesia. Email: rizafirdaus88@yahoo.-co.id. Mobile: 08565056311. 